\title{
PEMBERDAYAAN IBU-IBU DESA SRIMULYO MELALUI PENDAMPINGAN PEMBUATAN TING-TING JAHE ASRI GUNA MENINGKATKAN PEREKONOMIAN KELUARGA
}

\author{
Rahaju1), Ida Fitriyah'2), Yeni Puspitaningpuri²), Ernawati'2), Muslimatun Hasanah²), Nur Azizah²), \\ Tatik Retno Murniasih ${ }^{1)}$, Trija Fayeldi'), Timbul Yuwono') \\ 1)Pendidikan Matematika, Fakultas Sains dan Teknologi, Universitas PGRI Kanjuruhan Malang, Malang, Jawa Timur, \\ Indonesia \\ 2)Pendidikan Guru PAUD, Fakultas IImu Pendidikan, Universitas PGRI Kanjuruhan Malang, Malang, Jawa Timur, \\ Indonesia \\ Corresponding author : Tatik Retno Murniasih \\ E-mail : tretnom@unikama.ac.id
}

Diterima 29 November 2021, Disetujui01 Desember 2021

\begin{abstract}
ABSTRAK
Covid-19 menyebabkan banyak buruh pabrik desa Srimulyo di-PHK. Kondisi ini mengakibatkan perekonomian keluarga mengalami penurunan. Hasil pengamatan awal menunjukkan hampir semua halaman rumah warga ditanami jahe. Kurangnya pengetahuan warga menyebabkan jahe hanya digunakan sebagai minuman dan bumbu dapur. Jahe belum diolah dengan berbagai macam olahan lain. Pengabdian ini bertujuan untuk meningkatkan perekonomian keluarga Desa Srimulyo melalui pendampingan pembuatan ting-ting jahe ASRI. Metode yang ditawarkan dalam pengabdian antara lain pendampingan pembuatan ting-ting jahe berupa pelatihan serta pengemasan dan pelabelan. Hasil pengabdian menunjukkan pengetahuan ibu-ibu Desa Srimulyo bertambah dalam pembuatan ting-ting jahe dan hasil penjualan ting-ting jahe dapat meningkatkan perekonomian keluarga. Diharapkan kegiatan pengabdian dapat dilanjutkan dengan pemasaran ting-ting jahe ASRI secara online.
\end{abstract}

Kata kunci: pemberdayaan; ting-ting jahe; perekonomian.

\begin{abstract}
Covid-19 has caused many factory workers in Srimulyo village to be laid off. This condition causes the family economy to decline. Initial observations show that almost all of the residents' yards are planted with ginger. Lack of knowledge of residents causes ginger is only used as a drink and a kitchen spice. Ginger has not been processed with various other preparations. This service aims to improve the economy of the Srimulyo Village family through assistance in making ASRI ginger ting-ting. The methods offered in the service include assistance in making ginger ting-ting in the form of training as well as packaging and labeling. The results of the service show that the knowledge of the Srimulyo Village women increases in making ginger ting-ting and the sales of ginger ting-ting can improve the family economy. It is hoped that service activities can be continued with online marketing of ASRI ginger.
\end{abstract}

Keywords: empowerment; ting-ting ginger; economy.

\section{PENDAHULUAN}

Pandemi Corona Virus 19 (Covid-19) berdampak pada berbagai sektor dan berbagai lapisan masyarakat. Pandemi Covid-19 juga dirasakan oleh warga Desa Srimulyo yang terletak di Kecamatan Dampit Kabupaten Malang. Sebelum masa pandemi covid-19, banyak warga Desa Srimulyo yang berprofesi sebagai buruh pabrik dan penjual makanan. Akan tetapi, adanya pandemi covid-19 mengakibatkan banyak buruh yang di-PHK karena pabrik tidak dapat berproduksi secara maksimal seperti sebelum pandemi covid-19. Hal ini menyebabkan banyak keluarga yang mengalami penurunan pendapatan. Kondisi ini pun mengakibatkan para penjual makanan mengalami penurunan konsumen secara sangat drastis karena penurunan pendapatan berdampak pada penurunan daya beli warga. Oleh karena itu, perlu dicari solusi agar warga dapat mengatasi kesulitan dan tetap bertahan hidup dalam menghadapi pandemi ini.

Untuk mengatasi masalah di atas, dilakukan identifikasi dan penggalian potensi yang dimiliki Desa Srimulyo. Desa Srimulyo terletak di Kecamatan Dampit, Kabupaten Malang sekitar $51 \mathrm{~km}$ dari Kota Malang. Desa Srimulyo berada pada ketinggian sekitar 500 mdpl dengan kondisi tanah yang subur. Beberapa tanaman yang tumbuh subur di Desa Srimulyo, antara lain jahe dan kopi. Hasil observasi menunjukkan bahwa di halaman 
rumah warga banyak tumbuh tanaman jahe (Zingiber officinale). Hasil wawancara dengan beberapa warga diketahui bahwa tanaman jahe digunakan untuk memenuhi kebutuhan sebagai bumbu masak atau minuman (wedang jahe) bagi keluarga mereka sendiri. Warga belum mengolah jahe dengan berbagai macam bentuk disebabkan kurangnya pengetahuan mengenai alternatif pengolahan jahe. Berdasarkan hasil analisis terhadap potensi dan kekurangan di Desa Srimulyo, maka pemecahan masalah yang dipilih adalah memanfaatkan jahe yang dimiliki warga untuk meningkatkan perekonomian warga.

Selanjutnya, dilakukan pencarian informasi mengenai manfaat jahe dan berbagai jenis olahan jahe. Jahe adalah tanaman suku Zingiberaceae yang mempunyai kandungan fitokimia dan fitonutrien. Kandungan zat dan nilai gizi setiap 100 gram jahe mentah dapat dideskripsikan antara lain: a) serat 3,6 gram, b) karbohidrat 17,86 gram, c) energi 79 kkal, d) zat besi 1,15 gram, e) sodium $14 \mathrm{mg}, \mathrm{f}$ ) potassium $33 \mathrm{mg}, \mathrm{g}$ ) vitamin $\mathrm{C} 7,7 \mathrm{mg}$, dan $\mathrm{h}$ ) protein 3,57 gram (Kawiji, dkk., 2011; Aryanta, 2019). Selain kandungan gizi yang dipaparkan di atas, rimpang jahe juga mengandung magnesium, fosfor, zeng, folat, vitamin B6, vitamin $A$, niacin, dan riboflavin dalam jumlah yang sedikit (Aryanta, 2019).

Penggunaan jahe sebagai bumbu masak sudah dikenal oleh masyarakat luas (Aryanta, 2019). Akan tetapi, belum banyak masyarakat mengetahui bahwa kandungan minyak atsiri dengan senyawa kimia aktifnya memungkinkan jahe dimanfaatkan untuk mencegah dan mengobati macam-macam penyakit, anti inflamasi dan antioksidan (Aryanta, 2019; Ahmed, dkk., 2000). Jahe juga dimanfaatkan sebagai parfum. Olahan jahe lainnya berupa sirup jahe, serbuk jahe instan sebagai bahan wedang jahe, permen jahe, awetan jahe, dan ting-ting jahe (Ngatirah \& Dewi, 2020).

Dengan mempertimbangkan kekayaan tanaman jahe yang dimiliki warga dan manfaat jahe sebagai obat dan sumber pangan, maka pengabdian ini memilih program pendampingan pembuatan ting-ting jahe. Produksi ting-ting jahe diharapkan meningkatkan pengetahuan ibu-ibu warga Desa Srimulyo, serta meningkatkan perekonomian warga.

\section{METODE}

Kegiatan pengabdian ini dimaksudkan untuk membantu warga Desa Srimulyo yang mengalami masalah ekonomi akibat pandemi Covid-19. Kegiatan ini diharapkan berkelanjutan agar ibu-ibu dapat membantu menopang perekonomi keluarga tanpa harus bekerja di luar rumah (Dewi, 2015). Kegiatan ini dilakukan sesuai alur berikut ini.

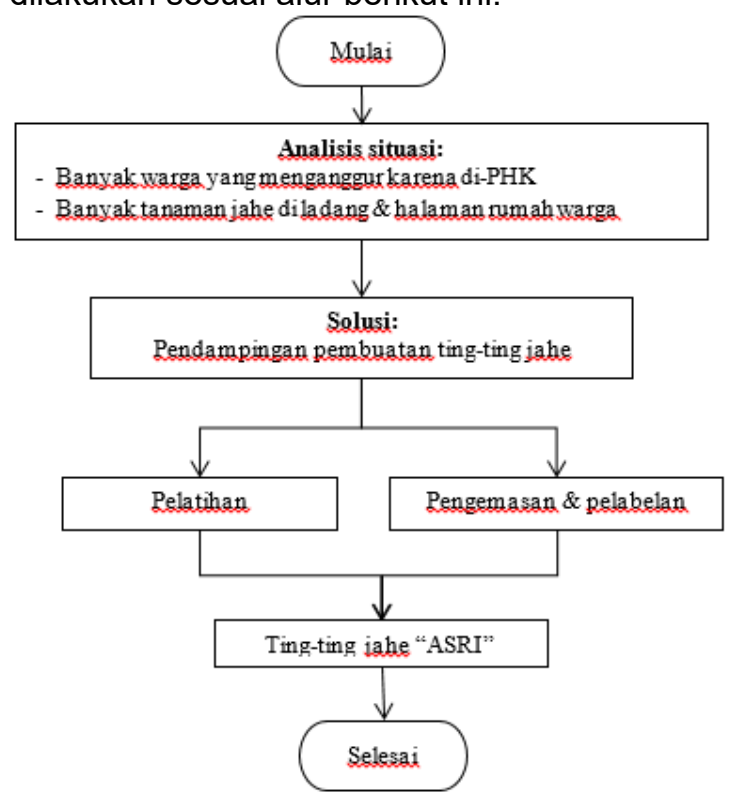

Gambar 1. Alur Kegiatan Pengabdian

Mitra kegiatan pengabdian ini adalah warga Desa Srimulyo. Pelaksanaan kegiatan pengabdian ini tetap memperhatikan protokol kesehatan yang dicanangkan pemerintah. Oleh karena itu, pelaksanaan pendampingan pembuatan ting-ting jahe dilakukan secara bertahap. Kegiatan pelatihan diberikan kepada kelompok inti, yaitu ibu-ibu pengurus tahlil Dusun Krajan Desa Srimulyo. Setelah kelompok inti memahami dan mengerti cara pembuatan ting-ting jahe, kelompok inti melakukan pendampingan kepada warga. Dengan demikian, tidak terjadi kerumunan dan warga tetap mendapatkan pengetahuan yang sama dalam proses pembuatan ting-ting jahe. Pola pengabdian digambarkan sebagai berikut. Mitra pengabdian ini berperan menyediakan tempat untuk kegiatan serta menyediakan alatalat yang akan digunakan untuk pengolahan ting-ting jahe.

\section{HASIL DAN PEMBAHASAN}

Hasil analisis situasi menunjukkan banyak tanaman jahe di halaman rumah warga dan perekonomian warga sedang menurun akibat pandemi Covid-19. Kegiatan pengabdian dilakukan dalam 4 pertemuan seperti ditunjukkan pada Tabel 1.

Tabel 1. Deskripsi Kegiatan Setiap Pertemuan

\begin{tabular}{cl}
\hline Pertemuan & \multicolumn{1}{c}{ Kegiatan } \\
\hline 1 & $\begin{array}{l}\text { Diskusi dan ceramah manfaat } \\
\text { jahe dan alternatif olahan jahe }\end{array}$ \\
2 & $\begin{array}{l}\text { Pendampingan pembuatan } \\
\text { ting-ting jahe }\end{array}$ \\
\hline
\end{tabular}




\begin{tabular}{ll}
\hline 3 & $\begin{array}{l}\text { Pengemasan dan pelabelan } \\
\text { hasil olahan ting-ting jahe }\end{array}$ \\
4 & Pola pemasaran \\
\hline
\end{tabular}

Kegiatan diawali dengan menjelaskan manfaat dan berbagai jenis olahan dari jahe. Setelah itu, dilakukan pendampingan pembuatan ting-ting jahe. Adapun alat dan bahan yang dibutuhkan adalah sebagai berikut. Alat yang digunakan yaitu: a) kompor, b) wajan, c) spatula, d) piring, e) parut, dan f) gunting. Bahan yang dibutuhkan yaitu: a) gula pasir 250 gram, b) wijen 150 gram, c) kelapa parut 250 gram, d) jahe parut 50 gram, dan e) daun pisang. Proses pembuatan ting-ting jahe dijelaskan berikut ini.

1. Kelapa diparut, jahe dikupas kemudian diparut. Kelapa, jahe, dan wijen disangrai secara terpisah hingga harum.

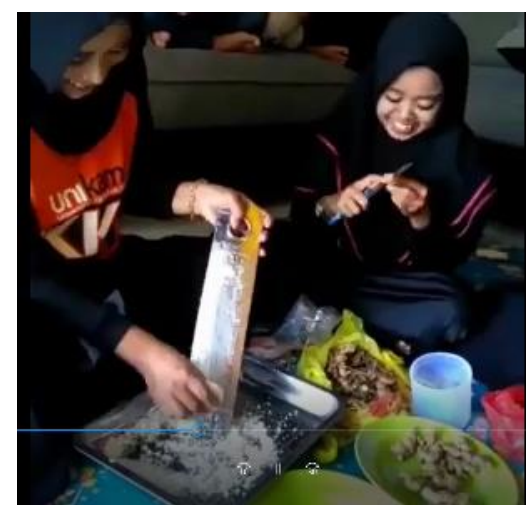

Gambar 2. Pemarutan dan Pengupasan Bahan

2. Gula pasir dipanaskan hingga meleleh menjadi karamel.

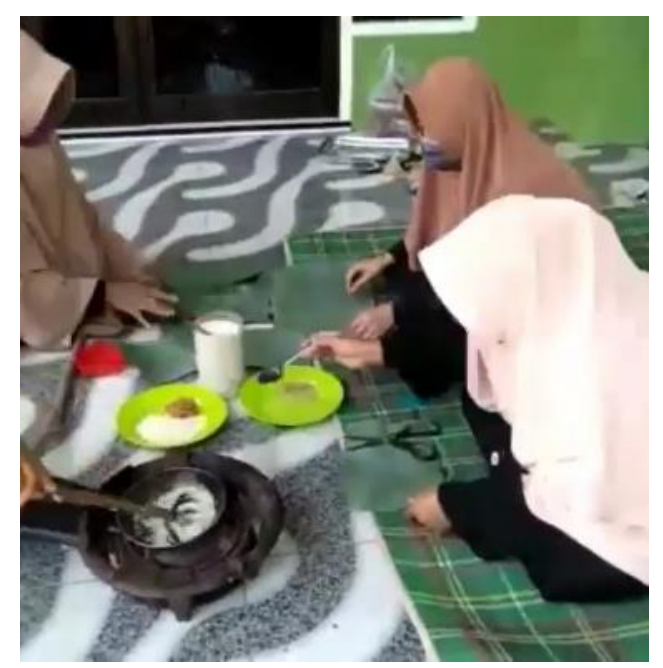

Gambar 3. Pembuatan Karamel
3. Masukkan kelapa, jahe, dan wijen, kemudian aduk hingga rata.

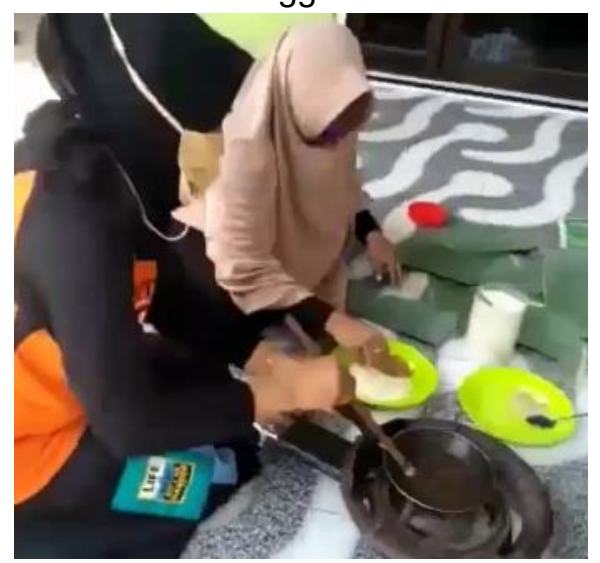

Gambar 4. Pengadukan Bahan

4. Tuangkan adonan ke atas daun pisang.

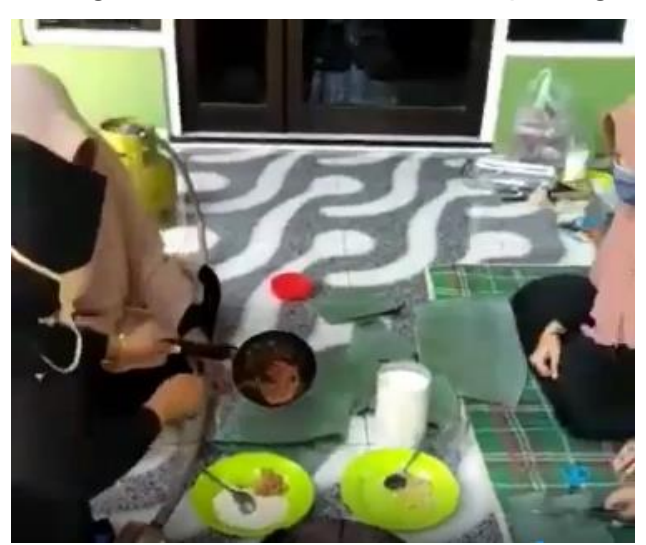

Gambar 5. Penuangan Adonan Di Atas Daun Pisang

5. Pipihkan dengan gelas.

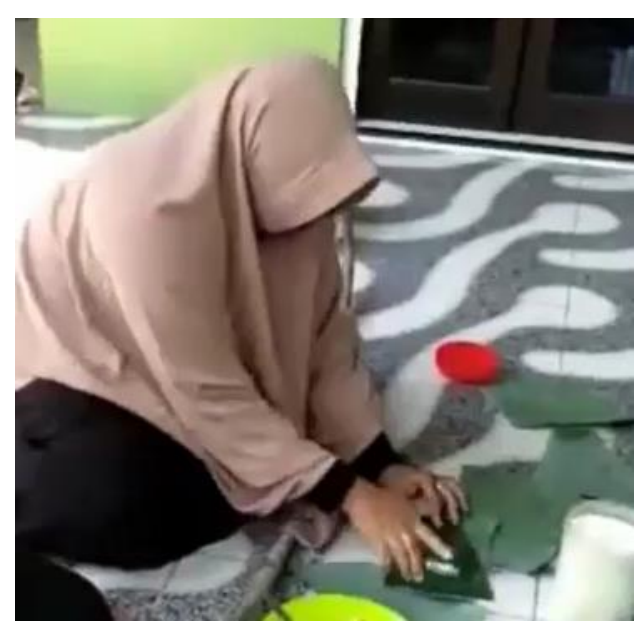

Gambar 6. Pemipihan Adonan 
6. Potong adonan dengan gunting hingga berbentuk segi empat

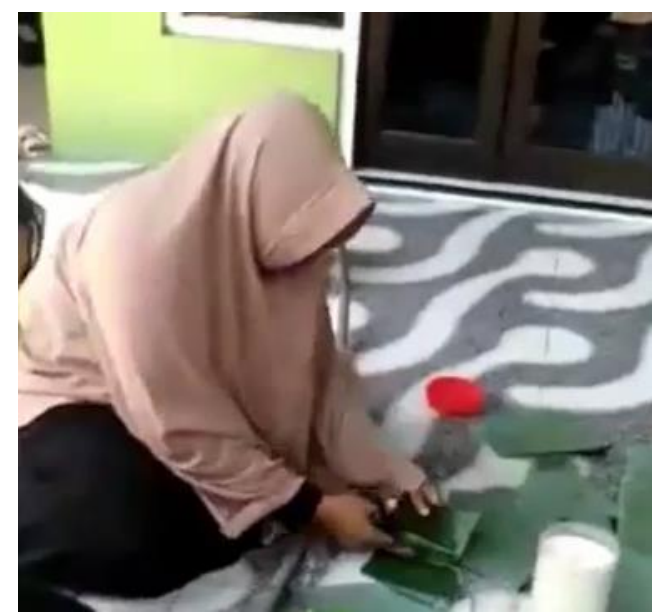

Gambar 7. Pemotongan Adonan

7. Gulung adonan sesuai dengan selera.

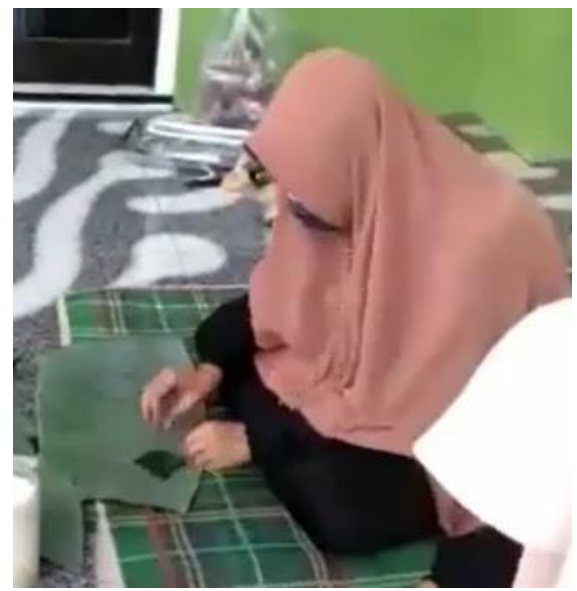

Gambar 8. Pemotongan Adonan

Pengemasan ting-ting jahe diawali dengan menempelkan label atau merk ting-ting jahe ke kantong plastik berukuran $1 \mathrm{~kg}$. Tingting jahe diberi merk "ASRI' singkatan dari "asli srimulyo". Ting-ting jahe yang sudah kering dimasukkan ke dalam kantong plastik yang sudah berlabel (Gambar 10.).

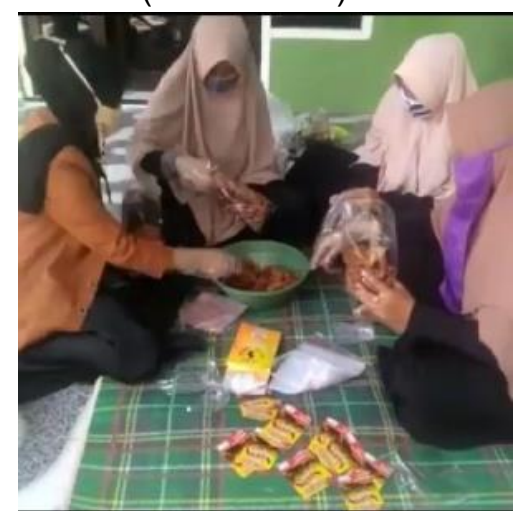

Gambar 10. Pelabelan Ting-tong Jahe "ASRI"
Setelah memahami cara pembuatan dan pengemasan Ting-ting Jahe Asri, kelompok inti ini mengajarkan dan mendampingi warga dalam pembuatan ting-ting jahe. Hasil produksi ting-ting jahe jamaah tahlil dikumpulkan di Paguyuban Jamaah Tahlil untuk dikemas dan diberi merk. Hasil akhir ting-ting jahe adalah sebagai berikut.

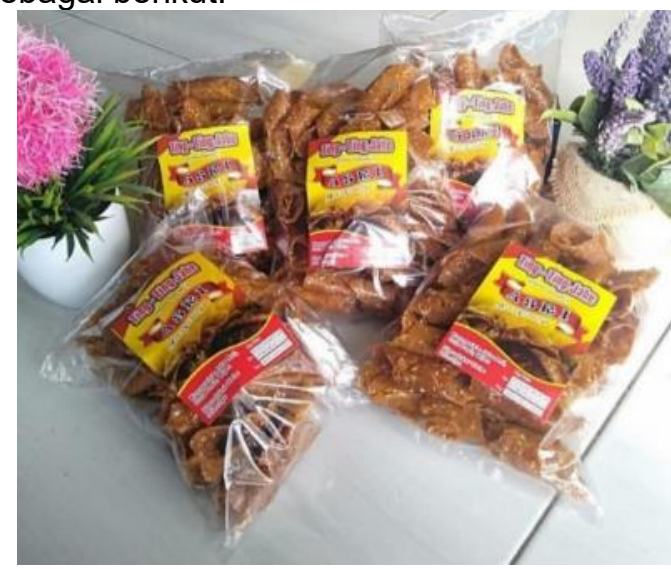

Gambar 10. Ting-ting Jahe "ASRI" yang Siap Dipasarkan

Paguyuban Jamaah Tahlil yang bertugas untuk menitipkan ting-ting jahe ini ke toko-toko. Hal ini dimaksudkan untuk menghindari persaingan harga dan kesulitan warga ketika harus memasarkan sendiri hasil produksinya (Mardhiyah \& Safrin, 2021). Berdasarkan kegiatan selama 4 kali pertemuan ibu-ibu merasa senang dan sangat antusias mengikuti kegiatan pendampingan dalam pelatihan, pengemasan dan pelabelan. Ibu-ibu mendapatkan bekal ilmu sehingga bisa melatih kemandirian dalam usaha (Yudiono, dkk., 2021).

\section{SIMPULAN DAN SARAN}

Kegiatan pengabdian ini menambah pengetahuan ibu-ibu warga Desa Srimulyo mengenai pembuatan ting-ting jahe. Ting-ting jahe yang dihasilkan dijual melalui Paguyuban Jamaah Tahlil. Hasil penjualan ini meningkatkan pendapatan warga, sehingga dapat meningkatkan kondisi ekonomi warga dalam menghadapi pandemi covid-19. Warga berharap kegiatan pengabdian dapat berkelanjutan dalam pemasaran secara online.

\section{UCAPAN TERIMAKASIH}

Ucapan terimakasih disampaikan kepada Kepala Desa Srimulyo yang memfasilitasi proses pembuatan ting-ting jahe serta Ketua LPPM Unikama yang memfasilitasi tim pengabdi untuk berkomunikasi dengan pihak Desa Srimulyo. 


\section{DAFTAR RUJUKAN}

Ahmed, R. S., Seth, V., Pasha, S. T., \& Banerjee, B. D. (2000). Influence of dietary ginger (Zingiber officinales Rosc) on oxidative stress induced by malathion in rats. Food and Chemical Toxicology, 38(5), 443-450. https://doi.org/10.1016/S02786915(00)00019-3.

Aryanta, I. W. R. (2019). Manfaat jahe untuk kesehatan. Widya Kesehatan, 1(2), 39-43. https://doi.org/10.32795/widyakesehatan. v1i2.463.

Dewi, D. A. L. (2015). Peran ibu rumah tangga dalam perekonomian keluarga studi kasus di desa Gunem kabupaten Rembang. Buletin Bisnis Dan Manajemen, 01(01), 38-45.

Kawiji, Utami, R., \& Himawan, E. N. (2011). Pemanfaatan jahe (Zingiber officinale Rosc .) dalam meningkatkan umur simpan dan aktivitas antioksidan "sale pisang basah." Jurnal Teknologi Hasil Pertanian, 4(2), 113-119. https://doi.org/10.20961/jthp.v0i0.13576.

Mardhiyah, A., \& Safrin, F. A. (2021). Persaingan usaha warung tradisional dengan toko modern. Jurnal Bisnis Dan Manajemen, 8(1), 91-99. https://doi.org/10.26905/jbm.v8i1.5454.

Ngatirah, N., \& Dewi, C. W. A. (2020). Pelatihan penggunaan mesin penggiling jahe dan pengolahan limbah ampas jahe menjadi bubuk jahe. SELAPARANG: Jurnal Pengabdian Masyarakat Berkemajuan, 4(1), 589-593.

Yudiono, U., Ferdiani, R. D., Farida, I. N. N., Murniasih, T. R., \& Rahaju, R. (2021). Pengenalan Jiwa Wirausaha Dan Manajemen Produksi Siswa Mts Miftahul Ulum Melalui Pelatihan Pembuatan Telur Asin. LOGISTA-Jurnal IImiah Pengabdian Kepada Masyarakat, 5(1), 280-284. https://doi.org/10.25077/logista.5.1.280284.2021. 